\title{
Effect of Exogenous Enzyme Supplementation of Dried Pulverized Unripe Plantain Peel Meal on the Performance and Carcass Characteristics of Finisher Broilers
}

\author{
Ikpe, J. $\mathbf{N}^{1}$., Okorie K. $C^{2}$., Oko, E. $C^{3}$ \\ ${ }^{1,3}$ Department of Agricultural Technology, School of Industrial Technology, Akanu Ibiam Federal Polytechnic, Unwana-Afikpo, Ebonyi \\ State
}

${ }^{2}$ Department of Animal Science And Fisheries,Facaulty of Agriculture And Veterinary Medicine, Imo State University, Owerri

\begin{abstract}
Dried plantain peel, a waste product collected from plantain chips processors was sundried, milled to obtain the meal. The meal was supplemented with exogenous enzyme (Nutrizyme) at the rate of 100grams per 100kgrams of the meal. The enzyme fortified meal, was used to formulate treatment diets. Treatment 1 was the experimental baseline (control) and treatments 2, 3 and 4 contained the fortified meal at 10\%, 15\% and 20\% respectively. The treatment diets were fed to a group of 120 four weeks old broilers of the Abor acres breed, randomly assigned to the treatment diets at 30 broiler per treatment. Each treatment group was subsequently replicated into 3 consisting of 10 broilers per replicate and raised on deep litter pen. The result of the experiment showed that the final live weight of broilers in treatment 1 is highest though not significantly different ( $p>0.05)$ from those in treatment 3 , while broilers in treatment 2 and then those in 4 were uniform but significantly different $(p<0.05)$ from those in treatment 3 . The average weight gain was uniform for broilers in treatment 1 , treatment 2 and treatment 3 , but significantly different $(p<0.05)$ between broilers in treatment 4 . The average daily feed intake was uniform between broiler in treatment 1 , treatment 2 and treatment 4 and significantly different ( $p<0.05)$ from broiler in treatment 4 . The average daily feed intake showed no significant difference between the treatments.
\end{abstract}

Keywords: Unripe plantain peel meal, Endogenous enzyme, Broiler production

\section{Introduction}

Plantain peel is an agricultural waste product which is obtained after utilizing the plantain pulp. Plantain is a crop from the genus musa. Its fruit is edible and used domestically as fried slices, plantain chips, plantain porridge while industrially, it is used in making flour for bread, cake for pancake, baby foods, wine, beer, dried flakes, biscuits and cookies.Nigeria is one of the largest producer of plantain in the world (FAO, 2013). She ranked first in Africa and fifth in the world producing 2,722,000 metric tons in 2011 (FAO, 2013). Plantain is among the foremost sources of carbohydrate in humid tropical Africa and contained 35\% carbohydrate, $0.2-0.5 \%$ fat, $1.2 \%$ protein and $0.5 \%$ ash (IITA, 2009). Oyenuga, (1968) has earlier reported that unripe plantain peel contains $10.6 \%$ crude protein, $8.10 \%$ true protein, $82 \%$ crude fiber, $9.57 \%$ ether extract, $61.14 \%$ nitrogen free extract, $12.83 \%$ total ash and $12.09 \%$ silica free ash. Plantain is one of the major staple food in Nigeria and had the highest percentage increase in output over years 1999 to 2003 implying the existence of huge market potentials (CBN, 2003). In view of the significant production level of plantain, its expansion potentials and its contributions to the economic development of Nigeria it becomes imperative to discover different avenues in which it's peeling can be utilized.

Poultry industry in Nigeria is fast growing and is the fastest means of bridging the animal protein consumption gap prevailing in the country (FAO, 2009). The industry has been unable to fulfill its challenges due to numerous constrains facing It, among which is high feeding cost, accounting for over $70 \%$ of total cost of production (Madubuike, 2012). To address this problem, effort is geared towards finding ways of utilizing waste products as feed ingredient in the poultry industry. The nutrient content of plantain peel places it as having potentials to be utilized in feeding animals though it is high in crude fiber.

Aluet al (2009), reported that although the use of commercial food enzyme has gained world-wide acceptability, its use in Nigeria is still not popular and recommended the use of exogenous enzyme for enhancing the digestibility of feed ingredients and in the use of cheaper quality materials for optimum performance.

Nutrizyme is a synthetic pharmaceutical enzyme product designed to improve the digestibility of the diets containing high fiber ingredients in mono-gastric animals. The enzyme is complex, containing a range of carbohydrases which hydrolyze a broad spectrum of carbohydrate polymers such as hemicellulose, pectin and glycan into low molecular weight fractions. It contains phytase, xylanase, glucanase, pectinase and hemicellulase. All these, enhances proper utilization of feed, proper weight gain, improved feed conversion ratio increased availability of protein, fats and carbohydrates (manufacturer's information).

This study therefore, is aimed at investigating the performance and carcass characteristics of finisher broilers fed varying levels of exogenous enzyme supplemented unripe pulverized plantain peel. 


\section{Materials and Method}

The plantain peel use for the experiment was collected from a plantain chip processor in Owerri, Imo State, in South East ecological zone of Nigeria. The plantain peels were sundried till it became crispy to a moisture content of about $9 \%$. The peels were then taken to a hammer mill and were milled to obtain the pulverized unripe plantain peel meal. Sample of the meal was taken to the laboratory for proximate analysis for the determination of dry matter (DM), crude protein (CP), crude fiber (CF), Ether Extract (EE), Ash and Nitrogen Free Extract (NFE) calculated as outlined by AOAC, 1995 (Table 1). The enzyme was blended with the meal at the rate of $100 \mathrm{gm}$ of the enzyme to $100 \mathrm{~kg}$ of the meal mixed until homogenous blending was obtained.

Table 1: Proximate composition of dried pulverized unripe plantain peel meal

\begin{tabular}{|l|c|}
\hline Nutrient & Proximate Composition (D M\%) \\
\hline Moisture & 9.68 \\
Crude Protein & 11.13 \\
Crude Fiber & 6.01 \\
Ash & 11.67 \\
Ether Extract & 9.53 \\
Nitrogen Free Extract & 51.98 \\
\hline
\end{tabular}

Enzyme Used for the Experiment: Nutrizym ${ }^{\mathrm{TM}}$ the exogenous enzyme use for the experiment was obtained from an agro product dealer in Owerri. The enzyme according to the manufacturer's description is a complex and stabilized enzyme mixture for an improved feed utilization and feed efficiency. It contains hemicellulase, pectosanase, protease, xylanase, arabinase, $\beta$ - glucanase, cellobiase, pectnase, protease, amylase and lipase and wheat starch as the carrier.

Potency Test for Enzyme Activity: Potency of the enzyme was tested at the laboratory using cellulose acetate and distilled water. One gram of cellulose acetate was mixed with $1.5 \mathrm{gm}$ of the enzyme was dissolved in $5 \mathrm{ml}$ of distilled water in a test tube and allowed to stand for 24 hours. The material was wholly suspended in the solution with air spaces clearly visible and the fluid deep straw in colored. Color of test material later became dirty brown with coarse material at the bottom of the test tube and lighter with finer material and air bubbles (foam) at the top of the mixture. This result confirms the potency of the enzyme.

Experimental Diet: The enzyme supplemented pulverized plantain peel meal was used to formulate four broiler finisher diets at $0 \%, 10 \%, 15 \%$ and $20 \%$ inclusion rate for treatment 1, 2, 3 and 4 respectively. The ingredient composition of the experimental diets is represented in table 2.

Table 2: Ingredient Composition of Experimental Diet

\begin{tabular}{|l|l|l|l|l|}
\hline Ingredients & $\mathbf{T}_{1}(0.00 \%)$ & $\mathbf{T}_{2}(10.00 \%)$ & $\mathbf{T}_{3}(15.00 \%)$ & $\mathbf{T}_{4}(20.00 \%)$ \\
Maize (yellow) & 55.00 & 45.00 & 40.00 & 30.00 \\
Enzyme supplemented pulverized unripe & & & & \\
plantain peel meal & 00.00 & 10.00 & 15.0 & 20.00 \\
Soya bean meal & 15.00 & 15.00 & 15.00 & 15.00 \\
Groundnut cake & 10.00 & 10.00 & 10.00 & 10.00 \\
Palm kernel meal & 6.00 & 6.00 & 6.00 & 6.00 \\
Brewers dried grain & 5.00 & 5.00 & 5.00 & 5.00 \\
Fishmeal & 5.00 & 5.00 & 5.00 & 5.00 \\
Bonemeal & 5.00 & 5.00 & 5.00 & 5.00 \\
Salt & 0.25 & 0.25 & 0.25 & 0.25 \\
Vitamin premix & 0.25 & 0.25 & 0.25 & 0.25 \\
DL-methionine & 0.25 & 0.25 & 0.25 & 0.25 \\
L-lysine & 0.25 & 0.25 & 0.25 & 0.25 \\
TOTAL & 100 & 100 & 100 & 100 \\
\hline
\end{tabular}

Table 3: Calculated chemical composition of the experimental diets

\begin{tabular}{|l|l|l|l|l|}
\hline Crude protein & 20.186 & 20.180 & 20.686 & 20.686 \\
Crude fibre & 3.76 & 3.76 & 3.66 & 3.46 \\
Ether extract & 4.21 & 3.81 & 3.61 & 3.21 \\
Calcium & 0.1326 & 0.0821 & 0.0816 & 0.0806 \\
Phosphorus & 0.4405 & 0.4315 & 0.427 & 0.418 \\
DL-Methionine & 0.3499 & 0.3319 & 0.3229 & 0.3049 \\
L-Lysine & 0.8699 & 0.8449 & 0.7919 & 0.8074 \\
Metabolizable energy Kcal kg & $2,930.2$ & $2,686.8$ & $2,541.1$ & $2,507.7$ \\
\hline
\end{tabular}

\section{Experimental Birds and Design}

A total of 120 Abor acres breed of finisher broiler of four weeks of age and of an average weight of $670 \mathrm{gm}$ were randomly assigned into 4 experimental groups of 30 broilers each. The 30 broilers were replicated 3 times to give 10 broilers per replicate and were raised on a deep litter pen. Feed and water were given adlibitum and proper routine management practices and medication adopted. Feed intake 


\section{International Journal of Science and Research (IJSR) \\ ISSN (Online): 2319-7064}

Index Copernicus Value (2013): 6.14 | Impact Factor (2014): 5.611

was obtained by subtracting the weight of left over feed from the weight of feed offered after 24 hours. The initial weight of the broilers were taken and subsequently weighed weekly to obtain their weekly weight gain. Other parameters evaluated, were daily weight gain and feed conversion efficiency. The experiment lasted for 35 days.

\section{Carcass and Organ Weight Assessment}

At the end of the 35 days feeding trial, 2 broilers were randomly selected from each replicate making a total of 6 broilers from each treatment and a total of 24 broilers for carcass evaluation. The broilers were tagged and starved of feed for 12 hours prior to slaughter while water was provided. The live weight of the broilers were obtained and then slaughtered by severing the jugular vein with a sharp knife. The slaughtered broilers were dipped in a hot water at a temperature of $70^{\circ} \mathrm{C}$ to pluck the feathers and the plucked weight recorded. The carcass were then eviscerated and the eviscerated weight recorded and cut into parts according to the method of Okorie (2006), assessed and then weighed. The parts and organs were expressed as a percentage of the live weight. The weight of the following parts were assessed and recorded; Breast muscle, thigh/ drum stick, back, neck, wing, and head.

\section{Data Analysis}

Data obtained were subjected to statistical analysis using analysis of variance (Steel and Torrie 1980) while treatment means were compared using Duncan New Multiple Range Test as described by Obi (1990).

\section{Results}

The result of the performance of the finisher broilers fed the varying levels of the exogenous enzyme supplemented pulverized unripe plantain peel is presented in presented in table 3. The initial live weights were uniform. The final live weight indicated a significant difference among the treatment groups with treatment 1 (2682g) being uniform with treatment 3 (2603g) and significantly different ( $\mathrm{p}<$ 0.05 ) from treatment 2 which also is uniform with treatment 4 . The result of average weight gain showed a uniform result for treatment 1, treatment 2 and treatment 3 but significantly $(p<0.05)$ higher from treatment 4 . The average daily weight gain followed the same trend with final live weight. Treatment 1 and treatment 3 were uniform and significantly $(\mathrm{p}<0.05)$ higher from treatment 2 and treatment 4 which were uniform. There is no significant difference $(p>0.05)$ between the treatment diets for average daily feed intake while the feed conversion ratio for treatment 1 , treatment 3 and treatment 4 were uniform and significantly different $(\mathrm{p}<0.05)$ from treatment 2.

Table 4: Performance of finisher broilers fed varying dietary levels of exogenous enzyme supplementation of unripe plantain peel meal

\begin{tabular}{|c|c|c|c|c|c|}
\hline \multicolumn{6}{|c|}{ Treatment levels of experimental diet } \\
\hline Parameters & $\mathrm{T}_{1}(0 \%)$ & $\mathrm{T}_{2}(10 \%)$ & $\mathrm{T}_{3}(15 \%)$ & $\mathrm{T}_{4}(\mathbf{2 0} \%)$ & SEM \\
\hline Initial Live Weight (g) & $670^{a}$ & $690^{2}$ & $650^{2}$ & $670^{2}$ & - \\
\hline Final Live Weight (g) & $2682^{\mathrm{a}}$ & $2591^{b}$ & $2603^{\mathrm{a}}$ & $2561^{b}$ & 3.78 \\
\hline Average Weight gain (g) & $2012^{\mathrm{a}}$ & $1901^{\mathrm{a}}$ & $1953^{a}$ & $1891^{b}$ & 4.93 \\
\hline Average daily weight gain & & & & & \\
\hline $\begin{array}{l}\text { ( } \mathrm{g} / \text { day) } \\
\text { Average daily feed intake }\end{array}$ & $57.49^{2}$ & $54.31^{b}$ & $55.8^{\mathrm{a}}$ & $54.28^{b}$ & 1.87 \\
\hline (g/day) & $177^{a}$ & $174^{a}$ & $179^{2}$ & $163^{3}$ & 0.55 \\
\hline Feed conversion ratio & 3083 & $330^{\circ}$ & $321:$ & 3000 & 0.32 \\
\hline Mortality & 0 & 0 & 0 & 0 & - \\
\hline
\end{tabular}

a.b.c.d Means within rows with different subscripts are significantly $\left(\mathrm{p}^{<0.05)}\right.$ different.

The result of carcass characteristics of the broilers fed with exogenous enzyme supplemented pulverized unripe plantain peel is shown in table 5 . The live weight of treatment 1 and 3 were uniform but significantly different $(\mathrm{p}<0.05)$ from treatment 2 and treatment 4 which were uniform. The plucked weight expressed in percentage to live weight showed a significant $(\mathrm{p}<0.05)$ result between all the treatment groups with treatment 4 having the highest value (88.4\%), followed by treatment $2(87.61 \%)$, treatment 1 (86.85\%) and finally treatment 2 (84.96\%). The result for eviscerated weight also showed a significant $(\mathrm{p}<0.05)$ result with treatment 1 having highest value, treatment 2 and treatment 3 being uniform and significantly $(\mathrm{p}<0.05)$ higher than treatment 4. The result for breast muscle was significantly $(\mathrm{p}<0.05)$ higher for treatment 3 , treatment 2 and treatment 4 were uniform and significantly $(\mathrm{p}<0.05)$ higher than treatment 1 . Thigh/drum stick result also had the same trend, treatment 3 having a significantly $(\mathrm{p}<0.05)$ highest result, followed by treatment 2 and treatment 4 that were uniform and significantly higher than treatment 1 . The result for back showed a significant difference $(\mathrm{p}<0.05)$ between all the treatment groups with treatment 4 having the highest value, followed by treatment 3, then treatment 2 and finally treatment 1 . The result for neck showed that treatment 3 having a significantly $(\mathrm{p}<0.05)$ highest score, followed by treatment 1 and treatment 4 that were uniform and significantly $(\mathrm{p}<0.05)$ higher than treatment 2 . 


\section{International Journal of Science and Research (IJSR) \\ ISSN (Online): 2319-7064 \\ Index Copernicus Value (2013): 6.14 | Impact Factor (2014): 5.611}

Table 5: Carcass characteristics of finisher broilers fed varying dietary levels of exogenous enzyme supplemented unripe plantain peel meal

Treatment levels of the experimental diet

\begin{tabular}{|l|l|l|l|l|l|}
\hline Parameters & $\mathrm{T}_{1}(\mathbf{0} \%)$ & $\mathrm{T}_{2}(\mathbf{1 0} \%)$ & $\mathrm{T}_{3}(\mathbf{1 5} \%)$ & $\mathbf{T}_{4}(\mathbf{2 0} \%)$ & SEM \\
Live weight (g) & $2601^{\mathrm{a}}$ & $2646^{\mathrm{a}}$ & $2583^{\mathrm{b}}$ & $2501^{\mathrm{b}}$ & 11.13 \\
Plucked weight (\%) & $86.85^{\mathrm{c}}$ & $84.96^{\mathrm{d}}$ & $87.61^{\mathrm{b}}$ & $88.40^{\mathrm{a}}$ & 9.10 \\
Eviscerated weight (\%) & $81.16^{\mathrm{a}}$ & $76.52^{\mathrm{b}}$ & $76.19^{\mathrm{b}}$ & $75.65^{\mathrm{c}}$ & 22.09 \\
Breast muscle (\%) & $19.16^{\mathrm{c}}$ & $20.87^{\mathrm{ab}}$ & $22.50^{\mathrm{a}}$ & $20.05^{\mathrm{b}}$ & 8.17 \\
Thigh/drum stick (\%) & $17.99^{\mathrm{c}}$ & $18.20^{\mathrm{b}}$ & $19.18^{\mathrm{a}}$ & $18.90^{\mathrm{b}}$ & 7.01 \\
Back (\%) & $16.64^{\mathrm{d}}$ & $19.37^{\mathrm{c}}$ & $21.72^{\mathrm{b}}$ & $22.27^{\mathrm{a}}$ & 12.12 \\
Neck (\%) & $6.35^{\mathrm{b}}$ & $6.29^{\mathrm{c}}$ & $6.48^{\mathrm{a}}$ & $6.39^{\mathrm{b}}$ & 0.9 \\
Wing (\%) & $10.13^{\mathrm{c}}$ & $9.94^{\mathrm{d}}$ & $10.82^{\mathrm{a}}$ & $10.35^{\mathrm{b}}$ & 3.7 \\
Head (\%) & $4.99^{\mathrm{a}}$ & $4.81^{\mathrm{b}}$ & $5.00 \mathrm{a}$ & $4.84^{\mathrm{b}}$ & 4.1 \\
\hline
\end{tabular}

a, b, c, d Means within rows with different subscripts are significantly $(\mathrm{p}<0.05)$ different.

The result of organ weights expressed as percentage of live weight of broilers fed varying dietary levels of exogenous enzyme supplement pulverized unripe plantain peel is presented in table 4. There was a significant difference $(\mathrm{p}<0.05)$ in the result obtained for gizzard with treatment 4 having the highest value, followed by treatment 3 and then treatment 2 which is uniform with treatment 1 . There were no significant difference ( $\mathrm{p}>0.05$ ) in the records obtained from heart, intestinal length and liver/gall bladder while the result for vent showed a significant difference $(\mathrm{p}<0.05)$ indicating that treatment 2 and treatment 3 are uniform and higher than treatment 1 and treatment 4 both of which were also uniform.

Table 6: Organ weights of finisher broilers fed varying dietary levels of exogenous enzyme supplementation of unripe plantain peel meal

Treatment levels of the experimental diets

\begin{tabular}{|l|l|l|l|l|l|}
\hline Parameters & $\mathbf{T}_{1}(\mathbf{0} \%)$ & $\mathbf{T}_{2}(\mathbf{1 0} \%)$ & $\mathbf{T}_{3}(\mathbf{1 5} \%)$ & $\mathbf{T}_{4}(\mathbf{2 0} \%)$ & SEM \\
Gizzard (\%) & $2.426^{\mathrm{c}}$ & $2.426^{\mathrm{c}}$ & $2.451^{\mathrm{b}}$ & $2.552^{\mathrm{a}}$ & 1.18 \\
Heart (\%) & 0.488 & 0.455 & 0.493 & 0.487 & $\mathrm{NS}$ \\
Vent (\%) & $3.190^{\mathrm{b}}$ & $3.438^{\mathrm{a}}$ & $3.594^{\mathrm{a}}$ & 3.235 & 1.67 \\
Intestimal length (cm) & 122.56 & 123.54 & 143.11 & 140.02 & NS \\
Liver/gall bladder (\%) & 1.745 & 1.693 & 1.859 & 1.807 & NS \\
\hline
\end{tabular}

The result of the cost effectiveness of using the varying levels of the exogenous enzyme supplemented pulverized unripe plantain in the diet of finisher broilers is presented in table 5. The result showed a steady decline in cost for producing the experimental diets starting from treatment 1 to treatment 4 . The cost of producing treatment 1 diet was the highest, followed by treatment 2 and treatment 3 while treatment 4 had the least cost. The total cost for feeding a broiler for the 35 feeding trial were N366.52, N326.20, N316.80 and N276.80 for treatment 1, treatment 2, treatment 3 and treatment 4 respectively.

Table 7: Cost Effectiveness of the Varying Dietary Levels of Exogenous Enzyme Supplemented Pulverized Unriped Plantain Peel

Treatment Levels of the Experimental Diets

\begin{tabular}{|l|c|c|c|c|}
\hline PARAMETERS & $\mathbf{T}_{1}(\mathbf{0} \%)$ & $\mathbf{T}_{2}(\mathbf{1 0 \%})$ & $\mathbf{T}_{3}(\mathbf{1 5} \%)$ & $\mathbf{T}_{4}(\mathbf{2 0} \%)$ \\
Total cost of feed produced (200kg) (f) & 13020.8 & 11553.6 & 10753.6 & 9954. \\
Cost of feed kg (f) & 65.6 & 57.77 & 53.77 & 49.77 \\
Daily feed intake (g) & 160.69 & 161.36 & 167.86 & 159.07 \\
Total feed consumed (g) & 5624.15 & 5647.6 & 5875.1 & 5567.45 \\
Cost of daily feed Intake bird/35days (f) & 11.2 & 9.6 & 9.6 & 8.0 \\
Total cost of feed Intake/bird/35days & 366.52 & 326.20 & 316.8 & 276.8 \\
Cost of 25kg of the Experimental Feed (1 bag of the experimental feed) (\#) & 1627.2 & 1444.8 & 1344.0 & 1244.8 \\
\hline
\end{tabular}

\section{Discussion}

Birds on control diet were uniform with birds on treatment 3 in final live weight, average daily weight, average weight gain and feed conversion efficiency. This result indicated that exogenous enzyme supplemented pulverized plantain peel compared favorably in replacing maize as an energy source in finisher broiler diet. This confirms the report of Babatunde (2003) which reported that plantain fruits unfit for human consumption and the peels are used for livestock feeding. The result however disagreed with the aspect of
Babatnde (2003) work which indicated that the low energy, low protein and high fiber content of dried banana or plantain peel suggests that even in the dried form, these materials will not be good replacement for materials such as maize or guinea corn in conventional diet. The enhanced performance of the broilers, fed the test diet may be attributed to the pulverization of the test material and the supplementation with exogenous enzyme which enhanced the digestion and absorption of the fiber diet by the broilers. This result agrees with the work of Okorie (2005) on the effect of dried pulverized rumen content on the performance 


\section{International Journal of Science and Research (IJSR) \\ ISSN (Online): 2319-7064}

Index Copernicus Value (2013): 6.14 | Impact Factor (2014): 5.611

and organ weight of finisher broiler were it was reported that the degree of pulverization affects feed intake. ChoctMigran (2004), reported that the inclusion of exogenous enzyme in feeding allows the use of wide range of ingredients without compromising bird's performance and provides great flexibility in least cost feed. Hence, the enzyme supplementation of the pulverized plantain peel, improved the enzyme activities, by acting as a buffer to the endogenous enzyme activity thus improving the utilization of the high fiber plantain peel. The exogenous enzyme and the pulverization may have contributed to the high level of absorption and conversion of nutrients into muscle tissue. This result agrees with Esonuet al. (2004), who reported that, milling and addition of exogenous enzyme may have aided the buildup of muscle and structural tissues of the experimental broilers.

The organ parameters showed no difference in the result from the control and those from test diets in the results for heart, intestinal length and liver/gal bladder while the gizzard and the vent that had difference, the control is still uniform with treatment 2 in the result for gizzard and uniform with treatment 4 in the result for vent. Also these organs were intact, no discoloration or pin point nodules or lesion on examination. This showed that the broilers were healthy and that both the plantain peel and the exogenous enzyme did not have any toxic effect on the experimental broilers. The result of the organ characteristics contrast the report of Bambose and Niba (1995), and Okorie (2009), which reported heavy liver weight of birds fed diets containing higher levels of raw cotton seed meal which suggested the presence of toxic factor in the diets.

The cost benefit analysis of the exogenous enzyme supplemented pulverized plantain peel in the feeding of broilers showed a progressive reduction in cost as the inclusion level increases. The cost for producing 25kilogram of control diet is N1627.20 while that for trial diets were N1444.80, N1344.00 and N1244.80 for treatment 2, treatment 3 and treatment 4 respectively. Despite this higher cost for producing the control diet, the final live weight, average weight gain, average daily weight, average daily feed intake and feed conversion efficiency of the birds were uniform with treatment 3 . The result showed that it is cheaper to produce birds on treatment 3 than the control diet without any adverse effect on the broilers.

\section{Conclusion}

The use of exogenous enzyme supplemented pulverized plantain peel meal as an energy source in broiler diets up to $20 \%$ inclusion level has shown good potentials on the broilers it was fed with. The performance, carcass and organ values were in line with the control diet though the broilers on $15 \%$ inclusion level has a uniform performance with the control in most of the parameters evaluated and moreover showed a reasonable gain in cost over the control diet. This study therefore recommends the use of exogenous enzyme supplemented pulverized unripe plantain peel meal at $15 \%$ inclusion level.

\section{References}

[1] Alu, S.E, Kaankuka, F.G and Oluremi, O.L.(2009). Effect of NutraseXyla $\square$ enzyme supplementation on nutrient digestibility by weaned pigs fed high fiber diets www.patnsukjournal.net/current issue publication of Nasarawa State University.

[2] Babatunde G.M. (2003) FAO Coporate document depository. Availability of banana and plantain products for animal feeding http://www.fao.org/docrep/003/t0554e/t0554e17.htm

[3] Bamgbose, A.M and Niba, A.T (1995). Carcass traits relative organ weights and gut characteristics of broiler chicken, fed cotton seed cake in in starter and finisher ration. J. Anim. Prod. Res.7: 100 - 115.

[4] Chot, Migran (2009). Enzymes for the feed industry: Past present and future Xxii world's poultry congress, Istanbul Turkey. $126-130$.

[5] IITA 2009: International Institute of Tropical Agriculture In Banana and Plantain. http://www.iita.org/banana and-plaintain.

[6] Madubuike, F.N (2012). Bridging the Animal protein supply and demand gap in Nigeria. Imo State University, Owerri, Nigeria. Inaugural lecture. Serial No.7.

[7] Esonu, B.O., Azubike, J.C. and Okwu, H.O. Okoli, I.C., Emenalom, O.O. (2004). Effect of enzyme supplementation on the performance of broiler finisher fed Microdesmispuberula leaf meal. International Journal of Poultry science, 3(2):112-114.

[8] FAO, 2013: Food and Agriculture Organization of the United Nations. Crop yield. http://faostat.fao.org/site/567/DesktopDefault.aspx?Pag eID=567\#ancor

[9] Obi, I.U.(1990).Statistical Methods of Dictating Differences Between Treatment Means. Snap Press $2^{\text {nd }}$ ed., Enugu, Nigeria pp 24-35.

[10] Okorie, K.C. and Ndubuisi, E.C. (2009). Solvent extracted sesame seed meal: Effects on hematological values, serological profiles and neural metabolites of finisher broilers. Journal of food and fiber prod.2(1): 570-578.

[11] Okorie, K.C. (2005) The effects of dried pulverized rumen content on the performance, carcass and organ characteristics of finisher broilers. Anim. Prod. Res. Adv. 1(2) 96-100.

[12] Okorie, K.C. (2006). Evaluation of Jacaranda mimosifolia T. (stans) leaf meal as Ingredient in finisher broilers diet. Performance carcass and organ weight Characteristics. Anim. Prod. Res. Adv. 2(1):44-46.

[13] Oyenuga, V.C. (1968). Nigeria's food and feeding stuffs, their chemistry and nutritive values. Ibadan University Press.

[14] Steel, R.G.D. and Torrie, J.H. (1980). Principles and procedures of statiatics. Biometric approach $2^{\text {nd }}$ ed. Mcgray Hill Books Co- New York. 